\title{
共通課題 平成市町村合併下における地域農林業と地域経営
}

一第 53 回地域農林経済学会大会報告—

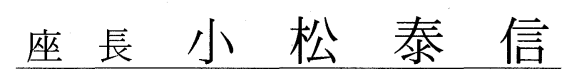

財政危機の深刻化や地方分権を背景として, 平 成の市町村合併が進められている.

本学会は, 市町村合併が地域農林業の維持・発 展に及ぼす影響を, 可能な限り把握し, 合併自治 体における地域農林業のあり方についての政策提 案をすべきと考えた，そして本シンポジウムにお いて, 地域経営という枠組みの中で, 地域農林業 のあり方を模索することによって，実効性のある 政策提案を行うこととした. もちろん, 市町村合 併そのものの是非を問うことも重要ではあるが, 本 シンポジウムでは, 市町村の再編を与件としたう えで, 地域農林業の発展の枠組みについて検討す ることとした，その検討結果は，合併を行わない 自治体にとっても, 少なからず有効と考えたから である。

報告者とコメンテイターからは, 多様かつ多角 的な知見が披瀝された，残念ながら，それらを統 一的に理解するまでには至っていないが，本シン ポジウムの齐らいに従い，これの知見に基づきな がら, 市町村合併下における地域農林業のあり方 に関する政策提案を行い，総括としたい.

第一には，まず住民が，その生活基盤とする自 治体の将来のあり方に, 興味と関心を深める環境 づくりである. それは, 住民主権という極めて重 要な、しかしこれまで必ずしも自覚的には認識さ れてこなかった統治（ガバナンス）問題を, 自ら の手に取り戻す貴重な契機となる，その契機づく りにおいて, 地域のリーダー層や自治体職員の問 題提起能力が重要な力ギを握ることになる.

第二には，公の責任放棄は許さない，という姿
勢を大前提とする中で，小自治組織（集落や旧村） における処方嘎は小自治組織自らが書く, という 自己決定 (自治) の原則を確立することである.そ のためには, 自治体内分権体制が認知されるとと もに, 小自治組織への権限と財源の移譲, そして 組織のあり方という, 制度設計が検討されねばな らない.

第三には, 新自治体における周辺地域の主要産 業である農林業に対する産業政策ビジョンづくり に関して, 農林業者や農林業関連団体が積極的に 参画することである.とりわけ中山間地において は，農業と林業を一体的にとらえた上で，生活の 領域も包摂した，地域政策的側面を強調すべきで ある，集落営農を例にあげれば，それは自主財源 の獲得手段という側面を持つとともに, 地域資源 の保全による生活環境の整備であり, 多面的機能 発揮を通じた地域の存在価值の発現, といった多 様な側面を有していることへの自覚的対応である. 集落営農のために集落があるのではなく, 集落の ために集落営農がある, という視座の転換である.

この国のかたちがいかなる流れを志向しようと, 従来の枠組みの中での対応では, この閉塞した地 域農林業は打開できないことは明らかである。こ の度の市町村合併を, 自治の仮面をした“他治”を 捨て去り，自己決定力に裏打ちされた住民自治を 手中に収め, 地域を経営する格好のチャンスと位 置づけることで, 地域の産業と生活は再生への第 一歩を歩み始めると言えよう.

（筆者：岡山大学） 